\title{
Role of Infrastructures in Explaining Trade Costs in ASEAN-5
}

\author{
Mohd Khairul Rafiz Ramli, Normaz Wana Ismail
}

\author{
University Putra Malaysia \\ 43400 Serdang, Selangor, Malaysia \\ E-mail:mkrafz@gmail.com,nwi@upm.edu.my
}

cross $^{\text {ref }}$ http://dx.doi.org/10.5755/j01.ee.25.2.2980

\begin{abstract}
Numerous studies have shown that infrastructure has a positive impact on international trade. For instance, benefit of infrastructure can be shared with many stakeholders especially with the poor ones in a remote area. Hence, a good infrastructure can lower market access restriction, opportunity costs and increase the likelihood of participating in the benefit of international trade. However, existing studies have mainly focused on the traditional determinants of trade costs such as distance and border effects overtime. The role of infrastructure towards trade costs was largely overlooked. Infrastructure is not just limited to public utilities but also includes information and communication technology (ICT), political and social network, and some aspect of soft infrastructure such as management practice, operating procedures and policies development. Some studies proved that infrastructure has significant and relatively large impact on trade flows especially in telecommunication infrastructure. Infrastructure development is important as a tool to speed up the economic integration within the region particularly in the area of international trade and investment. Efficient infrastructure can expand linkages to supply chain by lowering trade costs and increasing value added that is translated into potential profitability. As infrastructure expands, it motivates regional cooperation in infrastructure development, intraregional trade and broadens the investment that eventually lower the trade costs among countries. Following recent empirical studies that emphasize the importance of infrastructure, this paper examines the role of infrastructure in explaining trade costs in ASEAN-5 member countries namely Malaysia, Indonesia, Philippines, Singapore and Thailand. Arguably, countries with good infrastructure will have less trade costs and this empirical study aims at shedding a light on the role of infrastructure towards trade costs by grouping infrastructure into four types which are land, sea, air and ICT and utilities infrastructures. The rationale behind this is that this approach allows us to disentangle and estimate the role of the different modes of infrastructure towards trade costs. The analysis is based on panel data from 1980 to 2009. There are several important conclusions emerging from this analysis. First, in full sample observation, internet appears to be the most deterministic variable of trade costs in ASEAN-5. This finding is congruent with the view that the better the ICT infrastructure the more accessible information about the foreign market the traders will gain thus decreasing the costs to trade. In separate model, rail route significantly decreases trade costs in these regions. This support the empirical results that improvements in basic infrastructure increase the accessibility of goods form producer to consumer thus, lowering the trade costs significantly. Others such as paved road, energy, gasoline and diesel consumption used in road sector are equally important in explaining the trade costs through these regions.
\end{abstract}

Keywords: Infrastructures, Panel Data, Trade Costs, Trade, ASEAN-5.

\section{Introduction}

Economic historians have stressed out a remarkable role played by transportation through the intensity of infrastructure such as paved road and railways connection as the main driver increasing the trade worldwide. As world's economy sustained increases in the international commodity, capital and labor, those inventions are greatly helpful in moving goods to various ports and across nation (Hatton \& Williamson, 2006). This can be shown by the great increase in commodity market integration in the late $19^{\text {th }}$ century in the Atlantic economy, which was due to sharp decline in the transportation costs ( $\mathrm{O}^{\prime}$ Rourke \& Williamson, 1999)

Many researches argue that trade costs are imposed by the distance a product must travel to reach a market in a foreign country. The common explanation for this reason is that for international trade, transport costs are considerably increasing in distance. On the other hand, the large reduction in transport costs is mainly due to the improvement in various sectors such as infrastructure and communication technology that generate significant trade growth and reduce the importance of distance. Yet, many researches estimate the effect of distance on trade over time by employed gravity models. However the results are not conclusive. Some studies find a decrease in the elasticity of trade to distance, while most studies point to much less change or a modest increase (Disdier \& Head, 2008).

A better understanding of whether and how trade costs has changed over time are depend not only on the distance proxy alone but also on other possibilities explanations in order to conclude more general acceptance. Although trade costs phenomenon is not new in the international trade literature, there is little information on the size of trade costs and only partial evidence on their determinant. The foremost question in international trade literature is why do some countries have higher trade costs than other countries? What driven these phenomena and specifically 
what is the impact of infrastructure on these trade costs? A number of variables has been recognized in the literature as influencing trade costs. One such explanation is the use of CIF-FOB. The gap between free-on-board (FOB) values when a good reaches the port of exit in the exporting country and import values which include cost, insurance and freight (CIF) provides economically meaningful and operational measure of international trade costs.

The objective of this study is to determine the role of infrastructure on trade costs in ASEAN-5 region by employing panel data set from 1980 to 2009 . This paper is organized as follows. In Section 2, the literature is reviewed whilst the methodology and data are presented in the Section 3. Section 4 reports empirical results showing that the investigate variables are significant determinants of trade costs but their impact varies across between pooled regression and independent regression. Lastly a discussion on conclusion of the results is given in Section 5.

\section{Current Understanding of Trade Costs}

In general, trade costs can be defined as costs incurred in getting a good to a final user other than the distinctive marginal costs of producing the good itself. According to Anderson and Wincoop (2004) trade costs consist of transportation costs both freight costs and time costs, policy barriers in both tariff and non-tariff barriers, information costs, contract enforcement costs, costs associated with the use of different currencies, legal and regulatory costs and local distribution costs (wholesale and retail).

Trade costs and other transportation costs theory are mainly based on new trade theory developed by previous researchers such as (Krugman, 1979; Lancaster, 1980; Helpman, 1981; Deardoff, 1984) in the late 1970s and 1980 s. The beginning of this theory was driven by the failure of the traditional theories in order to explain some of the most significant international economics event ${ }^{1}$. According to (Helpman \& Krugman, 1985), conventional trade models like the Ricardian model and the HeckscherOhlin model were impossible to explain the most current economic phenomena.

A number of growing literature has documented the main issues of trade costs phenomenon, the determination of trade costs, and the impact of what it has brought. Eaton et al., (2004) focus on the spatial dimension of trade within a country, rather than external trade, and link the presence of the extensive margin to puzzles about the importance of distance and border effects in trade. Melitz (2003) argue that the role of fixed costs of trade is related with the producer heterogeneity in the consumer goods trade model. But (Hummels \& Klenow, 2005) are the ones who differentiated exports into extensive margin and intensive margin in response to the exporter characteristic. Numbers of studies have shown that countries would trade less with remote or distant partners. Yet, Obstfeld and Rogoff (2001) argue that transport costs cause the distance

\footnotetext{
1 According to Krugman (1979) in the beginning of $20^{\text {th }}$ century, economic theory such as the comparative advantage would have difficulties to explain the large share of trade occurred between the countries that have very similar characteristic. Likewise, the Ricardian model in determinants of comparative advantage lies outside of the model. Thus, the new trade theory was born.
}

effects. Grossman (1996), Hummels (2001), however, conclude that transport costs are too low to explain the magnitude of the distance effects, particularly after taking into account that gravity models can also explain the flow of weightless goods such as capital. Nevertheless, Huanga (2006) claims that not only transport costs but also unfamiliarity can explain the negative correlation between geographic distances and bilateral trade volumes and proposes a novel approach to disentangle the two effects, utilizing systematic variations of uncertainty-aversion across countries.

Also, according to Anderson and Wincoop (2004) who are well-known with trade costs definition, it is emphasized that 170 percent of representative trade cost in the industrialized countries can be divided into 21 percent transportation costs, 44 percent border related barriers and remaining 55 percent breaks down into retail and wholesale distribution costs. Novy (2007) added that bilateral trade costs are as a main driver of trade and emphasizes that to be consistent with the theory these must be measured relatively to trade costs with all other trade partners. Likewise et al., (2007) relate the degree of specialization in an economy to the interaction of comparative advantage and trade costs, and higher trade costs are reducing a country from taking advantage of the full potential gains from specialization and trade in order to promote economic development. In a global model of the pattern of bilateral trade, Waugh (2009) finds that regulated trade costs are systematically asymmetric, with poor countries facing higher costs to export their goods to rich countries; removing the asymmetry in trade costs, cross-country income differences decline by up to 34 percent. Importers may be concerned about time rather than financial costs.

According to (Promfret \& Sourdin, 2009), the useful gap between CIF (costs insurance and freight) and FOB (free-on-board) value of trade flows is a useful measure of aggregate trade costs in terms of consistent volume of trade. Using HS 6-digit level data from Australia import data they found that there was a large variation of trade costs in country-by-country. Distance, weight and size are accounted for the part of the variation in trade costs. Although institutions play a part in the trade cost variation, it's not uniform across mode of transportation and commodities. Exporting countries institutional quality is more strongly related to trade costs for air freight than sea freight and the relationship is commodity-specific and the strongest for manufactured goods.

On the other hand, there are several studies dedicated to trade costs that show that trade costs vary significantly among the countries and do not depend entirely on distance. Limao and Venables (2001) found a large variation in the cost of shipping a container from Baltimore to different countries, some of which are physically determined (landlocked countries have higher transport costs) but much of it is due to differences in infrastructure. While, Clark et al., (2004) came up with similar results for the costs of shipping a container from Latin American countries to the USA, and emphasized the quality of institutions such as corruption, logistical efficiency, and so forth as the key determinant of port efficiency. Shepherd (2010), shows that all trade costs consist of export costs, 
tariff, and international transport costs are robustly connected with geographical export diversification and concluded that, trade facilitation at home, which is custom procedures and documentation preparation, have a strong effect in improving market access abroad with manufacturing and highly differentiated sectors having the larger effects. Hummels (2001) emphasizes that decline in air transport costs relative to sea transport and the improvement in fast transport such as faster ocean liner are responsible for the increase of trade in time-sensitive goods. The advancement of much faster ocean liner was comparable to reducing tariff from 20 percent to 5,5 percent between 1950 and 1998. On the other hand (Ball et al., 2010; Czerny \& Zhang, 2011) study the airport pricing including the direct costs of flight delays in the US economy. The total cost of transport delays in 2007 was staggering $\$ 31,2$ billion and estimated to reduce the gross domestic product as much as $\$ 4$ billion.

Recent mainstream literature emphasizes the role of communication and information costs as an important variable in the bilateral trade. According to Rangan \& Lawrence, 1999; Casella \& Rauch, 2003, the difficulty of searching for matched buyers in an unfamiliar foreign country can create informational frictions and barriers for international trade, particularly for differentiated products. In the empirical research, Rauch (1999) finds that common language and/or colonial ties can overcome informational barriers in international trade and increase bilateral trade, mainly for differentiated products. Meanwhile, Head and Ries (1998) document the roles of immigrants in exchanging information and promoting bilateral trade between their host countries and their origin countries. (Freund \& Weinhold, 2000; Yi \& Choi, 2005), conclude that the internet has significant effects on international trade. The internet not just improves productivity but also can reduce inflation rate.

Another variable that is found to be important to bilateral trade is the communication and information costs. Evidences from (Rangan \& Lawrence, 1999; Casella \& Rauch, 2003) show that the difficulty of searching for matched buyers in an unfamiliar foreign country causes informational frictions and barriers for international trade, particularly for differentiated products. Rauch (1999) suggested that common language and/or colonial ties can overcome informational barriers in international trade and increase bilateral trade for differentiated products. In the recent years of technological evolution, access to the internet is another factor that is believed to have significant effects on trade. (Freund \& Weinhold, 2000; Yi \& Choi, 2005), conclude that the internet not only improves productivity, but also can reduce inflation rate, and the effects are much stronger in the developing countries. The findings of Petropoulou (2005) supported that improvement in information and communication technology increases the trade volume through the network.

\section{Research Methodology}

Many theories have shown that really good infrastructure will induce more trade thus, decrease trade costs overtime. There are numerous studies that support this relationship. However, some studies found that there are evidences that trade costs are less significant to the trade flows and there are other variables or proxies that should be considered to conclude more robust explanation of trade costs. This section covers model specification, variables definition and method that will be used in this paper. Data sources were World Development Indicator (WDI 2011) and Global Development Finance (GDF 2011) from the year 1980 to 2009. The equation is estimated using Fixed Effect Model (FEM) and Random Effects Model (REM). Hausman test is employed to determine between FEM and REM. Hausman test basically examines the null hypothesis. If the p-value is significant, the FEM is preferred. Likewise, if the p-value is insignificant, then the REM model is preferred. Thus, our model specification with the most basic equation is following:

Trade $=\beta_{0}+\beta_{1}[T C]+\varepsilon_{t l}$

Where TC can be defined as trade costs. We expand equation above into:

Ln $T C_{i t}=\beta_{1}$ ln Distance $_{i t}+\beta_{2}$ ln Internet It $+\beta_{3}$ ln Mobile $_{i t}+\beta_{4}$ ln Telephone $_{i t}+\beta_{5}$ ln Electric It $_{i t}+\beta_{6} \ln$ Rail $_{i t}+\beta_{7}$

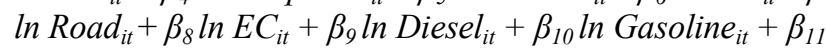
$\ln$ AirFreight $_{i t}+\beta_{12}$ ln AirRegister $_{i t}+\beta_{13} \ln$ Container $_{i t}+$ $\beta_{14} \ln$ Liner $_{i t}+e_{i t}$

\footnotetext{
Where:

Trade Costs (TC): Import CIF and Export FOB in ratio [(CIF/FOB)-1] for country i for the period $t$;

Distance: $\quad$ Internal distance of country $i$ for the period $t$;

Internet: Internet user to access the worldwide network of country $i$ for the period $t$;

Mobile: $\quad$ Mobile cellular subscription (per 100 people) of country $i$ for the period $t$;

Telephone: $\quad$ Fixed telephone line that connects a subscriber's terminal of country $i$ for the period $t$;

Electric: $\quad$ Production of power plants and combined heat and power plants less transmission, distribution, transformation losses and own use by heat and power plants measured in kwh per capita in country $i$ for the period of $t$;

Rail:

Road: Length of railway route available for the train service measured in total route per kilometer of country $i$ for the period $t$; Total paved road surfaced with crushed stone and measured percentage in length of country $i$ for the period $t$;

EC: Total country road sector energy consumption in petroleum products, natural gas, electricity and combustible renewable and waste in percentage of country $i$ for the period $t$;

Diesel: Diesel used as a fuel for internal combustion in diesel engines measured in kilo tone of country $i$ for the period $t$;

Gasoline: Light hydrocarbon used in internal combustion engine such as motor vehicles measured in kilo tone excluding aircraft of country $i$ for the period $t$;

Air Freight: $\quad$ Volume of freight, express and diplomatic bags carried on each flight stage in metric ton times kilometers travelled of country $i$ for the period $t$;

Air Register: $\quad$ Registered carrier departures domestic and abroad in the country $i$ for the period $t$;

Container:

Flow of port container traffic from land to sea transport in twenty foot equivalent units (TEU's) of country $i$ for the period $t$;

Liner: $\quad$ Liner shipping connectivity index of country $i$ for the period $t$;

$e_{i t}$

Error term.
} 
Next, from equation (2) we separate the model into land infrastructure, sea infrastructure, air infrastructure and ICT \& Utilties infrastructure.

\section{Land Infrastructure:}

$\operatorname{Ln} T C_{i t}=\beta_{1} \ln \operatorname{Rail}_{i t}+\beta_{2} \ln \operatorname{Road}_{i t}+\beta_{3} \ln E C_{i t}+\beta_{4} \ln$

Diesel $_{i t}+\beta_{5} \ln$ Gasoline $_{i t}+e_{i t}$

Sea Infrastructure:

Ln $T C_{i t}=\beta_{1}$ ln Container Cit $+\beta_{2} \ln$ Liner $_{i t}+e_{i t}$

Air Infrastructure:

Ln $T C_{i t}=\beta_{1}$ ln AirFreight ${ }_{i t}+\beta_{2}$ lnAir Register ${ }_{i t}+e_{i t}$

ICT and Utilities Infrastructure:

$\ln T C=\beta_{1}$ InInternet $_{i t}+\beta_{2}$ lnMobile $_{i t}+\beta_{3}$ lnTelephone $_{i t}$ $+\beta_{4}$ lnElectricity $_{i t}+e_{i t}$

Theoretically, the fields of trade costs are often difficult to test due to lack of a distinction. The main reason is that there are too many theories and models related to trade costs that must be considered. Thus, the determinant variables that have influence on the trade costs can be described as follows:

\section{a) Distance}

Recent study has shown that distance has a significant impact to the international trade flows. Promfret and Sourdin (2009) explain that distance, weight and size do account for the part of the variation of trade costs while (Anderson \& Wincoop, 2003; Bernard \& Jensen, 1999; Bernard et al., 2003) have witnessed the beginning of the importance of the wide spread margin in international trade relative to the distance. On the other hand (Leamer \& Levinsohn, 1995) found that there was a negative correlation between geographic distance and bilateral trade volumes. Hummels (2001) argues that transport costs are too low to explain the magnitude of the distance effects while Huanga (2006) claims that not only transport costs but also other factors such as unfamiliarity can explain the negative correlation between geographic distance and bilateral trade volumes.

\section{b) Land Infrastructure}

Over 23 percent of the world trades by value happen between the countries that share a common border (Hummels, 2001). Land infrastructure plays an important role in reducing the costs for trade. Poor infrastructure accounts for 60 percent of transportation costs for landlocked countries and the remaining 40 percent accounts for coastal countries (Limao \& Venables, 2001). Meanwhile et al., (2005) highlight the significance of transport infrastructure quality which is a percent of roads paved and quality of border-station customs services. Holl (2004) found that new road infrastructure has attracted a location for new manufacturing establishments.

\section{c) Sea Infrastructure}

Ocean transport has undergone various important technological changes in the last post-war era such as the introduction of containerization and the growth of open registry shipping practice. The rise in world trade has significant impacts on shipping costs through scale effects (Hummels 2001). Increase in demand for shipping container made the shipping capacity to become scarce and the costs rise dramatically. Over a long period however, the demand will actually decrease the shipping costs.

$$
\text { d) Air Infrastructure }
$$

Technological improvement in air carrier significantly affects the trade flows in terms of how the goods are being transported across international borders. The development of faster ocean vessel and jet aircraft has reduced the time for transportation of the goods and in the same time reduces the costs eventually (Gordon, 1990). Hummels (2001) identifies that air transport costs are one of the main reasons in the decline of costs to transport in time-sensitive goods.

e) Information Communication and Utilities Infrastructure

Communication and utilities costs are frequently cited as an important determinant of the trade costs. Petropoulou (2005) discovers that improvement in information and communication technology may increase the trade volume through the network. (Freund \& Weinhold, 2000; Yi \& Choi, 2005), have identified that the internet has significant impact on trade flows and inflation. The effects are much stronger for developing countries rather than the developed countries

\section{Empirical Results}

Fixed Effects Model (FEM) AND Random Effects Model (REM) are employed and Hausman test is conducted to choose between these two models. To check that this study is using an adequate model, Variance Inflation Factors (VIFs) and Correlation Test (Corr) are employed to indicate a level of multicollinearity. From the results, most of the variables show expected sign as usual in the gravity equation. Thus, the empirical results were.

Table 1 provides the descriptive statistics for the key variables in Fixed Effects and Random Effects. This table reports the results excluding the rail, energy, electric and container and liner coefficient due to severe collinearity problem and thus, these variables will regress independently in the next section. From the table above, under the Hausman test, it is clearly that Fixed Effects Model (FEM) is preferred. This is probably due to P-value in the null hypothesis was significant in all regressions. Thus, it is constant to make the use of FEM. Distance coefficient has expected signs in all regressions which suggested that distance $^{2}$ of country which is the average distance between producer and consumer will affect the costs of the goods travelling form the producer to the final consumer.

This finding is congruent to the studies of (Smith, 1955; Hummels, 2001; Anderson \& Wincoop, 2004) that, the further the distance, the higher the transport costs thus, increase the trade costs between trading countries. The internet coefficient has a significant and negative sign in the first column of FEM and it indicates the better ICT infrastructure where traders will gain the more accessible information about the foreign market thus, will decrease the costs to trade. Furthermore, gasoline and diesel coefficient has a significant and positive sign which shows that the higher the use of this hydrocarbon, the higher the trade costs are. This finding probably due to a large number of good transports using the diesel instead of gasoline in daily transportation does to costs effectiveness.

\footnotetext{
${ }^{2}$ Distance in this estimation is refered to Internal Distance by CEPII Distance classification
} 
Table 1

Impact of Infrastructures on Trade Cost: Full Sample

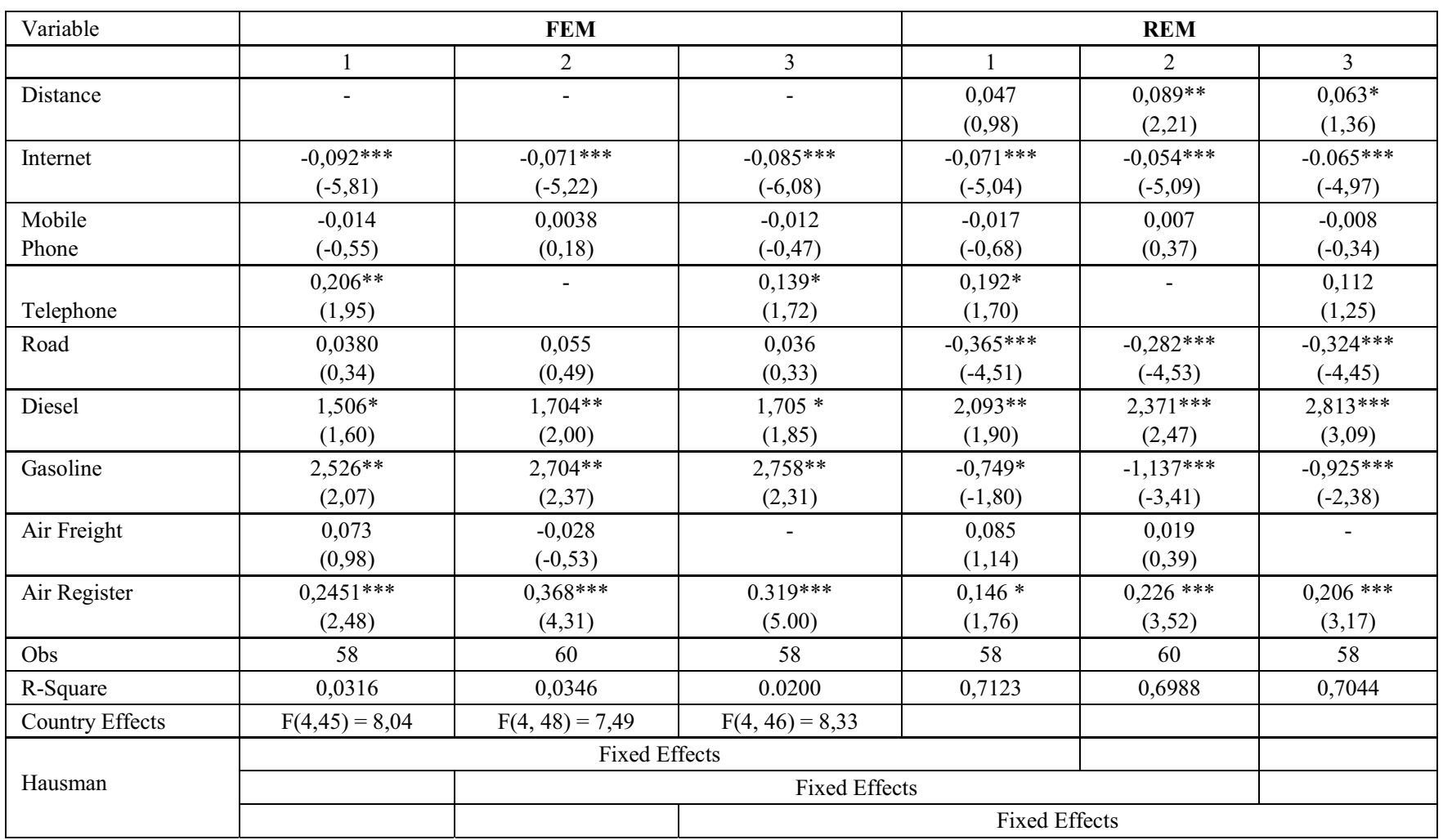

Notes: Numbers in parentheses are t-statistics. ${ }^{*}$ show significant level at 10 percent, ${ }^{* *}$ significant level at 5 percent and $* * *$ significant level at 1 percent.

Table 2

Impact of Land Infrastructures on Trade Cost

\begin{tabular}{|c|c|c|c|c|c|c|}
\hline Variables & \multicolumn{3}{|c|}{ FEM } & \multicolumn{3}{|c|}{ REM } \\
\hline & 1 & 2 & 3 & 1 & 2 & 3 \\
\hline Distance & - & - & - & $\begin{array}{l}0,167 \\
(0,49)\end{array}$ & $\begin{array}{l}-0,049 \\
(-0,80)\end{array}$ & $\begin{array}{c}0,541 * * \\
(2,12)\end{array}$ \\
\hline Rail & $\begin{array}{c}-0,549 * \\
(-1,36)\end{array}$ & - & $\begin{array}{l}-0,340 \\
(-0,86)\end{array}$ & $\begin{array}{c}-0,373 * * * \\
(-2,34)\end{array}$ & - & $\begin{array}{c}-0,436 * * * \\
(-2,75)\end{array}$ \\
\hline Paved Road & $\begin{array}{c}0,334^{*} \\
(1,74)\end{array}$ & $\begin{array}{l}0,176 \\
(1,01)\end{array}$ & $\begin{array}{c}0,431 * * \\
(2,30)\end{array}$ & $\begin{array}{c}0,401 * * * \\
(2,85)\end{array}$ & $\begin{array}{l}-0,016 \\
(-0,27)\end{array}$ & $\begin{array}{c}0,404 * * * \\
(2,80)\end{array}$ \\
\hline EC & $\begin{array}{c}-0,043 * \\
(-0,31)\end{array}$ & $\begin{array}{l}-0,022^{*} \\
(-1,78)\end{array}$ & - & $\begin{array}{c}-0,037^{*} \\
(-1,59)\end{array}$ & $\begin{array}{c}0,008 * \\
(1,53)\end{array}$ & - \\
\hline Diesel & $\begin{array}{l}-2,524 \\
(-1,63)\end{array}$ & $\begin{array}{l}0,113 \\
(0,09)\end{array}$ & $\begin{array}{l}-0,143 \\
(-0,10)\end{array}$ & $\begin{array}{l}1,557 \\
(1,07)\end{array}$ & $\begin{array}{l}-1,048 \\
(-1,08)\end{array}$ & $\begin{array}{l}-0,239 \\
(-0,25)\end{array}$ \\
\hline Gasoline & $\begin{array}{c}-3,280 * * * \\
(-2,24)\end{array}$ & $\begin{array}{c}-2,066^{* *} \\
(-1,94)\end{array}$ & $\begin{array}{l}-2,287 * \\
(-1,68)\end{array}$ & $\begin{array}{c}-2,578 * * * \\
(-4,61)\end{array}$ & $\begin{array}{c}-1,167 * * * \\
(3,10)\end{array}$ & $\begin{array}{c}-2,167 * * * \\
(-4,27)\end{array}$ \\
\hline Obs & 40 & 72 & 40 & 34 & 72 & 40 \\
\hline Country Effects & $\mathrm{F}(3,31)=0,21$ & $F(4,63)=2,34$ & $\mathrm{~F}(3,32)=0,03$ & & & \\
\hline \multirow{3}{*}{ Hausman } & \multicolumn{4}{|c|}{ Random Effects } & & \\
\hline & & \multicolumn{4}{|c|}{ Fixed Effects } & \\
\hline & & & \multicolumn{4}{|c|}{ Random Effects } \\
\hline
\end{tabular}

Notes: Numbers in parentheses are t-values. ${ }^{*}$ show significant level at 10 percent, ${ }^{* *}$ significant level at 5 percent and *** significant level at 1 percent

Table 2 shows the results for land infrastructure consisting of road, diesel, and gasoline with addition of rail and $E C$ (energy) coefficient that have been omit in the previous pooled regression. Distance coefficient is positive and significant as the longest distance between producers and consumers and thus increasing the trade cost. The rail coefficient has a significant and negative sign. This finding implied that improvement in basic infrastructure such as railways by 10 percent will generate 5 percent decrease in trade costs. Likewise, energy $(E C)$ coefficient also has a significant and negative sign. This is congruent with the study of $\mathrm{Li}$ et al., (2012) that decrease in energy 
consumption will reduce transport costs due to fuel burning efficiency in the transportation medium. However, transportation activities are known to generate externalities impact such as pollution and congestion. Thus, land infrastructures does not only suffer from the congestion their made, they also contribute to the pollution itself (De Borger and Proost, 2012 a,b). On the other hand, gasoline coefficient has significant and negative sign that indicates the higher the use of gasoline, the lower the trade costs. The result is contradict with the trade theory that the higher use of gasoline will increase the costs of transportation. Likewise, road coefficient has a significant and positive sign. This result is not congruent with the study of Limao and Venables (2001), Buys et al., (2010) found that improvement in the road infrastructure made the goods more assessable to transport and reduced the costs respectively. This is probably because the proxy of road, we used, is a paved road, meanwhile previous study uses total road network.

Impact of Sea Infrastructures on Trade Cost

\begin{tabular}{|c|c|c|c|c|c|c|}
\hline Variables & \multicolumn{3}{|c|}{ FEM } & \multicolumn{3}{|c|}{ REM } \\
\hline & 1 & 2 & 3 & 1 & 2 & 3 \\
\hline Distance & - & - & - & - & - & - \\
\hline Container & $\begin{array}{c}0,0968 \\
(1,05) \\
\end{array}$ & - & $\begin{array}{c}0,0738)^{*} \\
(1,64)\end{array}$ & $\begin{array}{c}-0,0424 \\
(-0,54) \\
\end{array}$ & - & $\begin{array}{c}-0,0802 * * * \\
(-3,04)\end{array}$ \\
\hline Shipping Liner & $\begin{array}{c}0,0255 \\
(0,28) \\
\end{array}$ & $\begin{array}{c}0,0675 \\
(0,82) \\
\end{array}$ & - & $\begin{array}{c}-0,1095 \\
(-1,27) \\
\end{array}$ & $\begin{array}{c}-0,1667 * * * \\
(-4,40)\end{array}$ & - \\
\hline R-Square & 0,7113 & 0,7508 & 0,3807 & 0,7476 & 0,7508 & 0,3807 \\
\hline Country Effects & $\mathrm{F}(4,23)=6,51$ & $F(4,24)=6,23$ & $F(4,44)=6,38$ & & & \\
\hline \multirow{3}{*}{ Hausman } & \multicolumn{4}{|c|}{ Fixed Effects } & & \\
\hline & & \multicolumn{4}{|c|}{ Random Effects } & \\
\hline & & & \multicolumn{4}{|c|}{ Random Effects } \\
\hline
\end{tabular}

Notes: Numbers in parentheses are t-statistics. * show significant level at 10 percent, ** significant level at 5 percent and *** significant level at 1 percent

Table 3 shows the results for sea infrastructure consisting of container and shipping liner as a proxy for port efficiency. Distance coefficient is omitted in both FEM and REM regressions due to severe collinearity between the variables. From the table it is clearly that these two variables are correlated with each other in a full regression in FEM. After omitting of one of the variables, both coefficients preferred REM. The shipping liner and container coefficients have negative and significant sign in REM. The result is congruent with Clarks et al., (2001) that increase in port efficiency will decrease the costs to trade. These findings provide evidence that port efficiency is essential to trade costs. Increase in the port efficiency will decrease the handling costs, nevertheless decrease the trade costs.

Impact of Air Infrastructures on Trade Cost

\begin{tabular}{|c|c|c|c|c|c|c|}
\hline Variables & \multicolumn{3}{|c|}{ FEM } & \multicolumn{3}{|c|}{ REM } \\
\hline & 1 & 2 & 3 & 1 & 2 & 3 \\
\hline Distance & - & - & - & $\begin{array}{l}0,023 \\
(0,55) \\
\end{array}$ & $\begin{array}{c}0,072 * * \\
(2,30)\end{array}$ & $\begin{array}{l}0,007 \\
(0,21) \\
\end{array}$ \\
\hline Air Freight & $\begin{array}{c}-0,063 * * \\
(-1,97) \\
\end{array}$ & - & $\begin{array}{c}-0,062 * * * \\
(-3,15) \\
\end{array}$ & $\begin{array}{c}-0,051^{*} \\
(-1,82) \\
\end{array}$ & - & $\begin{array}{c}-0,064 * * * \\
(-3,66) \\
\end{array}$ \\
\hline Air Register & $\begin{array}{l}0,0021 \\
(0,03) \\
\end{array}$ & $\begin{array}{c}-0,1162 * * * \\
(-2,86)\end{array}$ & - & $\begin{array}{l}-0,035 \\
(-0,58) \\
\end{array}$ & $\begin{array}{c}-0,123 * * * \\
(-3, .27) \\
\end{array}$ & - \\
\hline Obs & 150 & 150 & 150 & 150 & 150 & 150 \\
\hline R-Square & 0,2011 & 0,0226 & 0,2038 & 0,2348 & 0,2306 & 0,2014 \\
\hline Country Effects & $\mathrm{F}(4,143)=4,89$ & $\mathrm{~F}(4,144)=5,22$ & $\mathrm{~F}(4,144)=7,93$ & & & \\
\hline \multirow{3}{*}{ Hausman } & \multicolumn{4}{|c|}{ Random Effects } & & \\
\hline & & \multicolumn{4}{|c|}{ Random Effects } & \\
\hline & & & \multicolumn{4}{|c|}{ Random Effects } \\
\hline
\end{tabular}

Notes: Numbers in parentheses are $t$-statistics. ${ }^{*}$ show significant level at 10 percent, ${ }^{* *}$ significant level at 5 percent and *** significant level at 1 percent

Table 4 shows the results for air infrastructure consisting of air freight and air register with distance coefficient as a controlled variable. The air freight coefficient reported in significant and negative sign in REM. This result shows that increase in the volume of freight on each flight will lower the transport costs for the goods traveling and thus will decrease the trade costs. The distance coefficient reported in significant and positive sign indicates that increase in distance between trading partners implies higher the costs. The air register 
coefficient shows the same significant and negative sign. This result is congruent with the previous study of Gordon (1999) that the improvement of faster ocean vessel and jet aircraft has reduced the time to transport the goods and in the same time reduces the costs eventually.

Table 5 reported regression results of ICT and Utilities infrastructure on trade cost show that the higher numbers of internet users means that traders have easy access to information about the foreign market, therefore it lowers the costs of gaining such information thus, decreases the cost to trade. Almost all variables were insignificant in the first regression. However, taking out the internet variable out of the regression, we find REM as the preferred model, where all variables are significant and show the expected signs. The telephone coefficient is significant and has a negative sign, indicating that higher number of fixed line telephone subscribers suggest more access to foreign market, thus reducing the trade costs. Same goes for mobile phone coefficient. The higher the mobile cellular subscriptions, the better access of information, the lower the cost to trade.

Impact of ICT and Utilities Infrastructures on Trade Cost

\begin{tabular}{|c|c|c|c|c|c|c|}
\hline Variables & \multicolumn{3}{|c|}{ FEM } & \multicolumn{3}{|c|}{ REM } \\
\hline & 1 & 2 & 3 & 1 & 2 & 3 \\
\hline Distance & - & - & - & $\begin{array}{l}-0,007 \\
(-0,35)\end{array}$ & $\begin{array}{l}0,002 \\
(0,10)\end{array}$ & $\begin{array}{l}-0,018 \\
(-0,83)\end{array}$ \\
\hline Internet & $\begin{array}{c}-0,091 * * * \\
(-6,72)\end{array}$ & - & $\begin{array}{c}-0,091 * * * \\
(-6,71)\end{array}$ & $\begin{array}{c}-0,056 * * * \\
(-5,20)\end{array}$ & - & $\begin{array}{c}-0,033 * * * \\
(-4,60)\end{array}$ \\
\hline $\begin{array}{l}\text { Mobile } \\
\text { Phone }\end{array}$ & $\begin{array}{l}-0,034 \\
(-1,27)\end{array}$ & $\begin{array}{c}-0,047 * \\
(-1,49)\end{array}$ & - & $\begin{array}{c}0,045 * * * \\
(2,74)\end{array}$ & $\begin{array}{c}-0,016^{*} \\
(-1,35)\end{array}$ & - \\
\hline Telephone & $\begin{array}{l}0,070 \\
(1,15)\end{array}$ & $\begin{array}{l}0,037 \\
(0,53)\end{array}$ & $\begin{array}{l}0,030 \\
(0,57)\end{array}$ & $\begin{array}{l}0,022 \\
(0,59)\end{array}$ & $\begin{array}{c}-0,069^{*} \\
(-1,86)\end{array}$ & $\begin{array}{l}0,031 \\
(0,81)\end{array}$ \\
\hline Electric & $\begin{array}{c}0,806 * * * \\
(3,57)\end{array}$ & $\begin{array}{l}-0,069 \\
(-0,34)\end{array}$ & $\begin{array}{c}0,629 * * * \\
(3,53)\end{array}$ & $\begin{array}{c}-0,126^{* * *} \\
(-5,36)\end{array}$ & $\begin{array}{c}-0,096 * * * \\
(-3,74)\end{array}$ & $\begin{array}{c}-0,096 * * * \\
(-4,44)\end{array}$ \\
\hline Observation & 86 & 90 & 86 & 86 & 90 & 86 \\
\hline R-Square & 0,1829 & 0,4558 & 0,1648 & 0,5944 & 0,5287 & 0,5562 \\
\hline Country Effects & $F(4,77)=4,64$ & $\mathrm{~F}(4,82)=1,13$ & $\mathrm{~F}(4,78)=6,44$ & & & \\
\hline \multirow[t]{2}{*}{ Hausman } & & \multicolumn{4}{|c|}{ Random Effects } & \\
\hline & & & \multicolumn{4}{|c|}{ Fixed Effects } \\
\hline
\end{tabular}

Notes: Numbers in parentheses are $t$-values. Asterisks represents significance levels, * at 10 per cent, ** at 5 per cent and *** at 1 per cent.

The coefficient of utilities infrastructure measured by the electric is also significant and has negative sign. This result is consistent with previous studies which found higher production of electricity per capita facilitates producers to obtain adequate resources, and lowers the trade costs. In our analysis, a ten per cent increase in the production capacity of electric power plant reduces trade costs by as much as 1.2 per cent. All our findings provide evidences that improvement in communication and utilities infrastructure has a positive impact with better access to information and resources. Such improvement results in reducing trade costs and enhancing trade.

\section{Conclusions}

In effort to further understand the role of infrastructure on trade costs in ASEAN-5, this study provides empirical evidence that supports the importance of infrastructure in various modes by employing panel data. Trade costs play an important role in explaining various trades in ASEAN5. Since the introduction of the international trade theory, transport costs and other related trade costs can be distinctive between traded and non-traded commodities. This cost can be predictable to depend on other factor such as geographical, political and institutional factors. Our analysis proves that improvement in infrastructure such as paved road and railway routes facilitates the movement of goods from producers to consumers. Our result also supports the significance of transport infrastructure quality

to determine trade costs by making international trade faster, cheaper and easier for people and goods to move across within the region. Better infrastructure also helps to reduce poverty overtime by increasing access of poor's people to economic opportunities, welfare and the better access to basic infrastructure services such as electricity. Infrastructure development is crucial to realizing ASEAN goal of economic integration and as a single base market. Nevertheless, it is important for ASEAN countries to be physically connected by roads, railways, airways and seaports in order to promote cross-border trade, investment, to increase competitiveness and raise domestic output. This is evident by highly significant road, rail, sea and air infrastructure in the regression that shows that efficient, secure and integrated transport cooperation among ASEAN members is needed for recognizing the full potential of ASEAN Free Trade Area (AFTA). This is consistent with the ASEAN Transport Action Plan, 2005, 2010, which promotes efficient door-to-door cargo transport and cross border transport facilitation.

The improvement of ICT and utilities are also found to be equally important, where good communication infrastructure decreases trade costs with easy access to information. In the last decade, Southeast Asia region trades are becoming much lighter. The composition of trade is shifting from heavy and bulky goods towards lighter and higher value goods and services. Advancement in ICT and utilities helps this region to increase trade significantly by reducing weight-to-value ratio of traded 
goods especially in ICT products and outsourced services. In addition, a secure and connected information and communication infrastructure is crucial for supporting the region's competitiveness and economic growth. This is evident by high significance in ICT infrastructure such as the internet and mobile phone that show better information and communication infrastructure, that this region will have better impact on trade in terms of accessibility of information that will decrease the trade cost significantly. Although efforts have been made to facilitate interconnectivity among ICT system, there is still a lack of cooperation of ASEAN member on improving trust and confident in the use of the internet for electronic payments and settlements. This improvement will eventually narrowing the development gap among ASEAN countries, thus creates better access to wider regional markets, production network and investment.

Meanwhile, the innovation in the ocean vessels during the last post-war era has raised the importance of shipping costs in trade costs. Changes in transport technology in air and sea freight has grown faster due to advancement in logistic services that made possible to trade with more places in less time and often at much lower costs. In this study, port efficiency is measured using port containers and linear shipping connectivity, and the results show that an increase in the port efficiency increases trade volume between the countries and lowers trade costs. This shows that there was a dynamic relationship between trade costs and transportation technology efficiencies. Lowering trade costs have made disintegration of the production process possible. This increase of trade in intermediate products has in turn driven a demand for timely and effective transport and logistics services. Therefore, since timeliness seems has become very important, arguably that the quality of transport infrastructure might have become a more important determinant of trade than in the past. Increasing port efficiency with rapid technological changes in shipping transportation and containerization can yield economies of scale to a country. Furthermore, an efficient infrastructure can lower transaction costs, increase value added, and raise potential profitability in global supply chains and distribution networks for producers and consumers. Country that is involved more in international trade will likely gain more from trade-related infrastructure than the one that is not.

Improvements in the quality of infrastructure can, however be costly and in the short and long term beyond the means of the state governments in most of the Asian countries. However, there are areas where improvements could be obtained at modest cost. Previously, trade costs in ASEAN were substantially low due to outward-looking policies, deregulation, openness and flexibility with attractiveness of monetary policies that have been implementing throughout this region. This certainty created a favorable condition for trade to growth and increased a volume of trade among member's countries. Moreover, on the other hand, quality of infrastructure can also create or reinforce a comparative advantage. Recent study shows that differences in the quality of infrastructure between the countries can explain differences in total factor productivity. Since sectors vary in how intensively they use services related to infrastructure and how dependent they are on good infrastructure, the impact of quality of infrastructure on total factor productivity changes between sectors. However, the inefficient infrastructure made the transition slow and time consuming than ever. Economists have agreed that infrastructure plays an important role in which import and export take place that depend not only on the volume of infrastructure but also on the quality of infrastructure. Improvement in infrastructure will create a positive impact on the trade and economic growth. Development in the road infrastructure such as in the rural area will not only reduce transport costs but also will reduce poverty respectively.

There is a growing agreement within ASEAN that infrastructure has an important role to achieve regional economic integration. ASEAN Economic Community (AEC) was established to form the ASEAN nation as a single, production base for the world market. It has a key role in designing programs that support and monitor trade facilitation and trade costs in this region. Evidence has shown that reduction on trade cost in this region do increase trade between trading countries. Land transportation infrastructure is one of the important modes of transportation in ASEAN-5 because most of the member countries were neighboring countries. In other words, the easier the good travel across country, the lower the trade costs thus, induced more trade. This would give huge advantage to ASEAN-5 as the region intensifies its trading on free trade area (FTA) agreements thus, would help to create a single Asian market. The benefit of FTA certainly will benefit not just to the economy but also to the wellbeing of its citizen. Reductions in trade costs resulting from infrastructure improvements or expansion are other means of trade facilitation, but trade facilitation can be defined in many ways. According to WTO, it primarily refers to simplifying or speeding up administrative documentation procedures at border crossings. In broader sense, it includes measures taken by both public and private sectors, reduction in nontariff barriers (NTB), and improvements in physical facilities to ease the movement of shipments by reducing time in transit.

Overall, the findings from this analysis on the role of infrastructure in explaining trade costs help to fill the gap in the international trade research, and hope to increase better understanding towards managing trade costs in ASEAN-5 countries. Importantly, appropriate policies and strategies can be drawn in order to further lower the trade costs and increase competitiveness among trading partners, as well as encouraging more trade within the region and with the rest of the world. 


\section{References}

Anderson, J. E., \& van Wincoop, E. (2004). Trade costs. Journal of Economic Literature, 42, 691-751 http://dx.doi.org/10.1257/0022051042177649

Ball, M., Barnhart, C., Dresner, M., Neels, K., Odoni, A., Perterson, E., Sherry, L., Trani, A., \& Zou, B., (2010). Total Delay Impact Study: A comprehensive Assessment of the Costs and Impacts of Flight Delay in the United States, NEXTOR, Available from: /http://www.isr.umd.edu/NEXTOR/rep2010.htmlS.

Bernard, A., B. \& Bradford, J. J. (1999). Exceptional Exporter Performance: Cause, Effect, or Both?" Journal of International Economics, 47(1), 1-26. http://dx.doi.org/10.1016/S0022-1996(98)00027-0

Bernard, A. B., \& Bradford, J. J. (2004). Why Some Firms Export. Review of Economics and Statistics, 2003, 86(2).

Blonigen, B., Wilson, W. (2006). New Measures of Port Efficiency using International Trade Data. NBER Working Paper No. 12052

Buys, P., Uwe D., \& Wheeler D. (2006). Road Network Upgrading and Overland Choi, C. (2002). Does the Internet Stimulate Inward Foreign Direct Investment?. Journal of Policy Modeling, 25, 319-326

Clark, X., Dollar D., \& Micco, (2004). Port Efficiency, Maritime Transport Costs and Bilateral Trade. Journal of Development Economics, 75, 417-50 http://dx.doi.org/10.1016/j.jdeveco.2004.06.005

Coulibaly, S., \& Fontagn'e, L. (2006). South-South Trade: Geography Matters. Journal of African Economies, 15(2), 313-341. http://dx.doi.org/10.1093/jae/eji030

Czerny, A. I., \& Zhang, A., (2011). Airport congestion pricing and passenger types. Transportation Research Part B 45, 595-604. http://dx.doi.org/10.1016/j.trb.2010.10.003

Hummels, D. (2001). Have International Transportation Costs Declined?. Journal of International Economics 54(1), 7596. http://dx.doi.org/10.1016/S0022-1996(00)00093-3

Hummels, D. (2007). Have International Transportation Costs Decline?. Journal of Economic Perspective, 21(3).

Hummels, D., \& Klenow, P. J. (2005). The Variety and Quality of a Nation's Exports. American Economic Review, American Economic Association, 95(3), 704-723. http://dx.doi.org/10.1257/0002828054201396

De Borger, B., \& Proost, S., (2012a). A political economy model of road pricing. Journal of Urban Economics 71, 79-91. http://dx.doi.org/10.1016/j.jue.2011.08.002

De Borger, B., \& Proost, S. (2012b). Policies to Reduce Traffic Externalities in Cities, Discussion Paper.

Deardorff, A. (1998). Determinants of Bilateral Trade: Does Gravity Work in a Neo-Classical World?" in: Regionalization of the World Economy. J. Frankel (ed.), University of Chicago Press, Chicago.

Disdier, A. C., \& Head, K. (2008). The Puzzling Persistence of the Distance Effect on Bilateral Trade. The Review of Economics and Statistics, 90(1), 37-41. http://dx.doi.org/10.1162/rest.90.1.37

Jonathan, E., \& Kortum, S., \& Kramarz, F. (2004). Dissecting Trade: Firms, Industries, and Export Destinations. American Economic Review, Papers and Proceedings, 93, 150-154.

Fink, C., Mattoo, A., \& Neagu, I. C. (2005). Assessing the Impact of Communication Costs on International Trade?". Journal of International Economics, 67, 428-445 http://dx.doi.org/10.1016/j.jinteco.2004.09.006

Freund, C., \& Weinhold, D. (2004). On the effect of the internet on international trade. Journal of International Economics, 62, 171-89 http://dx.doi.org/10.1016/S0022-1996(03)00059-X

Gordon, R. J. (1990). What Is New-Keynesian Economics?. Journal of Economic Literature, September, 1990(b), 28, 1115-1171.

Grossman, G., (1998). Determinants of bilateral trade: does gravity work in a neoclassical world?". by A.V. Deardorff. In: Frankel, J. A. (Ed.). The Regionalization of the World Economy. The University of Chicago Press, Chicago.

Helpman, E., \& Krugman, P. R., (1985). Market Structure and Foreign Trade: Increasing Returns, Imperfect Competition, and the International Economy. MIT Press, Cambridge.

Hill, H. (2004). Six Asian Economies: Issues and Lessons. In Brooks, D. H. and H. Hill, eds., Managing FDI in a Globalizing Economy: Asian Experiences, London: Palgrave

Macmillan, 29-78.

Adelheid, H. (2004a). Manufacturing Location and Impacts of Road Transport Infrastructure: Empirical Evidence from Spain. Regional Science and Urban Economics, 34, 341-363. http://dx.doi.org/10.1016/S0166-0462(03)00059-0

Krugman, P. R. (1979). Increasing Returns, Monopolistic Competition and International Trade. Journal of International Economics, 9, 469-479. http://dx.doi.org/10.1016/0022-1996(79)90017-5 
Lancaster, K. (1980). Intra-Industry Trade under Perfect Monopolistic Competition. Journal of International Economics, 10, 151-175 http://dx.doi.org/10.1016/0022-1996(80)90052-5

Leamer, E., \& Levinsohn, J. (1995). International trade theory: the evidence. Handbook of International Economics, 3. Amsterdam, North-Holland, 1339-1394.

Limao, N., and, Venables, A. J. (2001). Infrastructure, geographical disadvantage, transport costs and trade. The World Bank Economic Review, 15(3), 451-479. http://dx.doi.org/10.1093/wber/15.3.451

Markusen, J., \& Venables, A. J (2007). Interacting factor endowments and trade costs: a multicountry multi-good approach to trade theory. Journal of International Economics, 73, 333-354. http://dx.doi.org/10.1016/j.jinteco.2007.03.005

Melitz, M., (2003). The Impact of Trade on Intra-Industry Reallocations and Aggregate Industry productivity. Econometrica, 71,1695-1725. http://dx.doi.org/10.1111/1468-0262.00467

Novy, D. (2008). “Gravity redux: Measuring international trade costs with panel data. Warwick Economic Research Paper No. 861 .

Obstfeld, M., \& Rogoff, K., (2001). The six major puzzles in international macroeconomics: is there a common cause?. In Bernanke B. and K. Rogoff (Eds.), NBER Macroeconomics Annual 2000. Cambridge, MA: MIT Press.

Dimitra, P. (2008). Information costs, networks and intermediation in international trade. CEPDP, 848. Centre for Economic Performance, London School of Economics and Political Science, London, UK. ISBN 9780853282419

Pomfret, R., \& Sourdin, P. (2010). Trade facilitation and the measurement of trade costs. Journal of International Commerce, Economics and Policy, 1(1), 145-163. http://dx.doi.org/10.1142/S179399331000010X

Rauch, J. (1999). Networks versus Markets in International Trade. Journal of International Economics, 48, 7-35. http://dx.doi.org/10.1016/S0022-1996(98)00009-9

Shepherd, B. (2010). Trade costs and facilitation in APEC and ASEAN: Delivering the goods?", in ESCAP, Rising Nontariff Protectionism and Crisis Recovery, (ST/ESCAP/2587).United Nations. Available from internet:

http://www.unescap.org/tid/artnet/pub/tipub2587.

Tang L. (2006). Communication costs and trade of differentiated goods. Review of International Economics, $14,54-68$. http://dx.doi.org/10.1111/j.1467-9396.2006.00560.x

Waugh, M. (2009). International trade and income differences. Federal Reserve Bank of Minneapolis Research Department Staff Report 435, available at http://www.minneapolisfed.org/research/sr/SR435.pdf. Accessed 2 December 2009.

Yi, M. H., \& Choi, C., (2005). The effect of the Internet on inflation: panel data evidence. Journal of Policy Modeling, 27(7), 885-889. http://dx.doi.org/10.1016/j.jpolmod.2005.06.008

Mohd Khairul Rafiz Ramli, Normaz Wana Ismail

Infrastruktūrų vaidmuo aiškinant prekybos kaštus ASEAN-5 regione

Santrauka

Prekybos kaštai atlieka svarbų vaidmenį norint paaiškinti daugeli prekybos sandorių ASEAN-5 regione. Atsiradus tarptautinės prekybos teorijai, transporto kaštai ir kiti, su prekyba susiję kaštai, gali išsiskirti tarp prekiu, kuriomis prekiaujama ir kuriomis neprekiaujama. Mūsu rezultatai atskleidția transporto infrastruktūros kokybès svarbą, kad ţmonès ir prekès tarptautinès prekybos regione judètų greičiau, pigiau ir lengviau. Empiriniai rezultatai rodo, kad atstumas turi didelę ịtaką prekybos kaštams ir prekybos srautams. Šis tyrimas yra iš dalies panašus ị ankstesnius tyrimus, kuriuos atliko Bernard ir Jensen (1999), Anderson ir Winccop (2004) ir kuriuose teigiama, kad atstumas daro itaką prekybai, o Pomfret ir Sourdin (2009) patvirtina, kad atstumas tai pat yra prekybos kaštų kitimo dalis.

Iš tikruju, ASEAN šalims yra svarbi infrastruktūra. Norint skatinti tarptautine prekyba, investicijas, taip pat didinti konkurencinguma bei vietinès gamybos apimtis reikia, kad. jos būtų sujungtos keliais, geleţinkeliais, oro ir jūrų keliais. Todèl akivaizdu, kodėl didţiulè reikšmė teikiama kelių, geleținkelių, oro ir jūrų kelių infrastruktūros regresijai. Șis rezultatas atitinka Coulibaly ir Fontagne (2006) bei Holl (2004a) rezultatus, kuriuose pabretțiama transporto infrastruktūros kokybès reikšmė prekybai ir prekybos kaštams. Juose pabrèțiama, kad efektyvus, saugus ir integruotas bendradarbiavimas transporto srityje tarp ASEAN narių yra reikalingas tam, kad būtų pripațintas visas ASEAN Laisvos prekybos zonos (ASEAN Free Trade Area - AFTA) potencialas. Tai atitinka ASEAN Transporto veiksmu plana 2005, 2010 metais, kuris skatina efektyvų krovinių gabenimą nuo „durų-iki-durų“ bei palengvinimą gabenimo per sieną.

Šiame darbe taip pat nagrinėjami informacijos, komunikacijos ir technologijos (IKT) bei komunaliniu paslaugu kaštai ir daroma išvada, kad šie kaštai vienodai svarbūs ASEAN-5 regiono prekybos kaštams. Interneto, mobiliojo telefono ir telefono koeficientai buvo pațymèti kaip svarbūs ir neigiami ț enklai nepriklausomos regresijos prekybos kaštuose. Tai atitinka ankstesnius tyrimus, kuriuose teigiama, kad komunikacijų infrastruktūros gerinimas sumat ins fiksuotus kaštus, informacijos bus daugiau ir ji bus laisviau prieinama, pigesne prekiautojams. Tai taip pat padès sumat inti prekybos kaštus. Pastaraisiais dešimtmečiais, Pietryčių Azijos regiono prekyba tapo daug paprastesne. IKT ir komunalinių paslaugų paț anga padeda šiam regionui gerokai padidinti prekyba, kartu sumaținant prekiaujamu prekiu svorio ir vertes santyki ( ypač IKT produktu ir perkamu paslaugu). Be to, saugi ir sujungta informacijos ir komunikacijos infrastruktūra yra lemiama, skatinant regiono konkurencinguma ir ekonominị augimą. Tai akivaizdu iš to, kokia didelè svarba yra teikiama IKT struktūrai, tokiai kaip internetas ir mobilusis telefonas. Regionai, kurių informacinè ir komunikacinė infrastruktūra yra geresnè, turès didesne itaka prekybai informacijos pasiekiamumo prasme ir tai gerokai sumaţins prekybos kaštus. Nors buvo dedama pastangu norint palengvinti IKT sistemos tarpusavio jungtis, vis dar trūksta ASEAN narių didinant pasitikejjimą bendradarbiavimu, kai naudojamas internetas elektroniniams mokejjimams ir atsiskaitymams. Siekis sumaţinti plètros spragas tarp ASESAN šalių, suteiks daugiau galimybių prieiti prie platesnių regioniniu rinku, gamybos tinklo ir investavimo.

Pokyčiai transporto technologijų srityse gabenant krovinius oru ir jūromis padidejo dèl logistikos paslaugų tobulèjimo. Jos suteikè galimybę prekiauti su daugiau kompanijų skirtingose vietose. Laikas buvo trumpesnis, o kaštai maț esni. Kaip parode Promfret ir Sourdin (2010), maț esni prekybos 
kaštai leido išskaidyti gamybos procesą. Taip buvo galima padidinti prekybą tarpiniais gaminiais, kurie taip pat lèmè efektyviu transporto ir logistikos paslaugų pasirinkimą. Tai patvirtina ir sutampa su Hummels (2001) rezultatais, kurie taip pat atskleidț ia maț esnius oro transporto kaštus lyginant su jūrų transportu. Tai, kad savalaikiškumas tampa labai svarbiu veiksniu, transporto infrastruktūros kokybè turètų tapti lemiančiu prekybos veiksniu, nei anksčiau. Gerèjantis uosto paslaugu teikimas dèl technologijų diegimo laivininkystės transporto paslaugu ir konteinerių gabenimo, šaliai gali būti naudingas dèl ekonomikos masto didèjimo. Tam turi įtaką didesni ir greitesni laivai, kurie sumaţ ina gabenimo laiko vidurkị jūroje ir uostuose. Hummels (2007) parodo, kad didinant konteinerinès prekybos dali 1 proc., gabenimo kaštai sumațeja nuo 3 iki 13 procentu. Taip pat sumaținti sandoriu kaštus gali ir efektyvi infrastruktūra. Taip pat reikia padidinti pridètinę vertę ir galimą pelningumą pasaulinèse tiekimo grandinėse ir paskirstymo tinkluose gamintojams ir vartotojams. Salis, kuri daugiau ịsitraukia ị tarptautinę prekybą, susietą infrastruktūra, turès daugiau naudos nei ta šalis, kuri tuo neuțsiima. Ankstesni darbai parodé, kad infrastruktūra yra pagrindinis lemiamas veiksnys ne tik kalbant apie eksportą, bet taip pat ir apie visas eksportavimo galimybes.

Tačiau, nors infrastruktūros kokybès gerinimas gali būti brangus tiek trumpu, tiek ir ilgu laikotarpiu, yra sričiu, kur tai pasiekti galima uț mațesnę kainą. Pirma, ASEAN regiono prekybos kaštai yra gana maţi dẻl išorés politikos, valstybès reguliavimo panaikinimo, atvirumo ir lankstumo kartu su monetarinès politikos patrauklumu, kurie buvo įdiegti regione. Tai tikrai sukuria palankias sąlygas prekybai augti ir apimtims didèti tarp asociacijos šalių narių. Taip pat, infrastruktūros kokybė gali sukurti arba sustiprinti santykinị pranašumą. Paskutinis tyrimas parodo, kad infrastruktūros kokybės skirtumai tarp šalių gali padèti paaiškinti bendro veiksnio našumo skirtumus. Kadangi sektoriai skiriasi tuo, kiek intensyviai jie naudoja su infrastruktūra susijusias paslaugas ir kiek jos priklauso nuo geros infrastruktūros, infrastruktūros kokybės įtaka bendram veiksnio našumui sektoriuose kinta. Tačiau neefektyvi infrastruktūra padaro perèjimą lètesniu ir ilgesniu, nei kada nors būdu. Ekonomistai pritarè tam, kad importas ir eksportas uţima tokią vietą, kuri priklauso ne tik nuo infrastruktūros apimties, bet taip pat ir nuo infrastruktūros kokybès. Infrastruktūros tobulinimas turi didelę teigiamą ịtaką prekybai ir ekonominiam augimui.

ASEAN Ekonomine bendrija (AEB) buvo sukurta norint suformuoti ASEAN valstybę kaip atskirą gamybinę bazę pasaulio rinkai. Ji atlieka pagrindini vaidmenị kuriant programas, kurios remia ir kontroliuoja prekybos palengvinimą ir prekybos kaštus šiame regione. Poț ymiai parodè, kad prekybos kaštų maţinimas šiame regione didina prekybą tarp prekiaujančiu šalių. Pavyzdţiui, ț emès transporto infrastruktūra yra vienas iš svarbiausių transportavimo tipų ASEAN-5 regione, nes dauguma asociacijos šalių narių yra kaimyninès šalys. Ținoma, kuo lengviau prekès keliauja per šalį, tuo maţ esni prekybos kaštai, taigi, labiau skatinama prekyba. Tai suteikia didţiuli privalumą ASEAN-5 regionui, nes regionas intensyvina savo prekybą pagal laisvosios prekybos zonos (AFTA) susitarimus, taip padèdamas kurti atskirą Azijos rinką. AFTA teikiama nauda neabejotinai bus naudinga ne tik šaliai, bet ir jos gyventojų gerovei. Prekybos kaštu mațejjimas, atsiradęs dèl infrastruktūros tobulinimu ar plètros, yra kita prekybos palengvinimo priemonè, kuri gali būti įvairi. Tiesą sakant, anot Pasaulinès prekybos organizacijos (PPO), pirmiausiai jis reiškia administracinių dokumentavimo procedūrų kertant sieną supaprastinimą arba pagreitinimą, kurie apima viešujų ir privačių sektorių procedūras, netarifinių barjerų (NTB) sumaținimą ir fizinių sąlygų gerinimą, norint palengvinti krovinių judèjimą sutrumpinant tranzito laiką.

Šio tyrimo rezultatai suteikia daugiau mokslinès informacijos tyrimams susijusiems su tarptautine prekyba. Tikimasi, kad jie padès geriau suprasti prekybos kaštu valdymą ASEAN-5 regiono šalyse. Standartinis panelinis modelis atskleidția, kad ț emès, oro, jūru transporto infrastruktūra ir IKT bei komunalinių paslaugų infrastruktūra yra vienodai svarbios, aiškinant prekybos kaštų veiksnius ASEAN-5 regione. Remiantis Fiksuotu efektu modeliu (FEM) ir atsitiktiniu efektu modeliu (REM), beveik visi kintamieji igyja laukiamą pokytị visose trijose regresijose. Svarbiausia, galima pasinaudoti atitinkamomis politikomis ir strategijomis, norint toliau maţinti prekybos kaštus ir didinti konkurencingumą tarp prekybos partnerių, taip pat skatinti prekybą regiono viduje ir su kitomis pasaulio šalimis.

Raktaţ odț iai: infrastruktūros, paneliniai duomenys, prekybos kaštai, ASEAN-5 regionas.

The article has been reviewed.

Received in December, 2012; accepted in April, 2014. 